\title{
1,3-Dienes from ketones via the Shapiro reaction
}

\author{
Matthew S. Addie and Richard J. K. Taylor* \\ Department of Chemistry, University of York, Heslington, York YO10 5DD, UK \\ E-mail: rjkt1@york.ac.uk
}

This paper is dedicated to Professor Otto Meth-Cohn to mark his $65^{\text {th }}$ birthday and to acknowledge his many contributions to synthetic and heterocyclic chemistry

(received 21 Apr 00; accepted 03 Oct 00; published on the web 11 Oct 00)

\begin{abstract}
1,3-Dienesare prepared from ketones by an efficient two step procedure. Ketone-derived trisylhydrazones are subjected to an organolithium-induced Shapiro reaction to produce the corresponding vinyllithium species. Transmetallation to organocopper intermediates then allows efficient dimerisation to a range of alkyl substituted 1,3-dienes. Some limitations of the procedure are also described.
\end{abstract}

Keywords: 1,3-Dienes, Shapiro reaction, vinyllithium reagents, vinylcopper reagents, dimerisation

\section{Introduction}

1,3-Dienes are important synthetic intermediates, finding particular application in the DielsAlder reaction. ${ }^{1}$ We have a long-standing interest in the preparation of conjugated polyenes ${ }^{2,3}$ and recently reported a convenient entry to 1,4-disubstituted buta-1,3-dienes via the palladium(II)-mediated homocoupling of organostannanes. ${ }^{4}$ In seeking to convert ketones 1 into 2,3-disubstituted- and more highly substituted butadienes 4, we envisaged a new extension of the Shapiro reaction ${ }^{5}$ (Scheme).

Thus, conversion of the ketones 1 into the corresponding sulfonylhydrazones 2 followed by the organolithium-induced Shapiro reaction is known to produce vinyllithium intermediates $3{ }^{5} \mathrm{We}$ planned to transmetallate 3 to produce a vinyl organometallic species which would undergo dimerisation to give dienes 4 . 


$$
\text { Tris } \left.=2,4,6-\left({ }^{(} \mathrm{Pr}\right)_{3} \mathrm{C}_{6} \mathrm{H}_{2} \mathrm{SO}_{2^{-}}\right)
$$

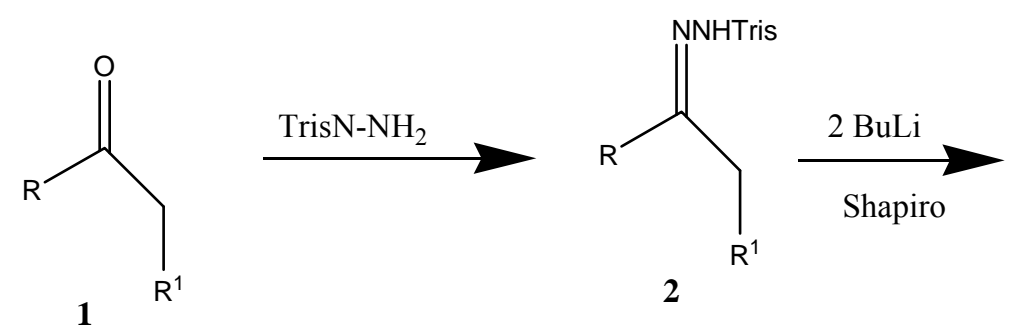

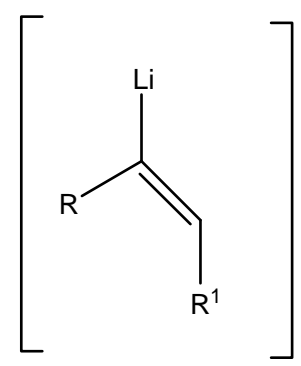

3

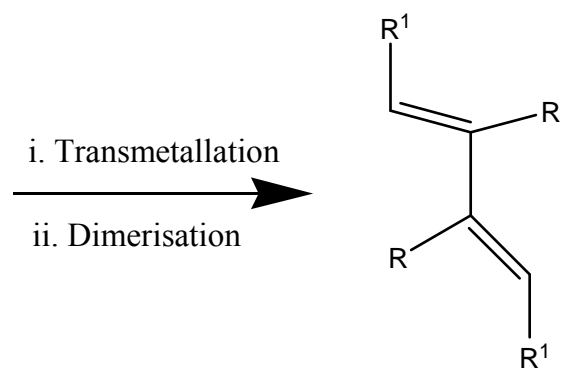

4

\section{Scheme 1}

\section{Results and Discussion}

Initial studies were carried out with tosylhydrazones but it was soon established that better results were obtained using 2,4,6-triisopropylbenzenesulfonyl (trisyl) hydrazones. ${ }^{5 \mathrm{~b}}$ The trisylhydrazones $2 \mathrm{a}-\mathrm{h}$ were readily prepared, most in almost quantitative yield (Table), simply by stirring a THF solution of the appropriate ketone and trisylhydrazide and then removing the solvent in vacuo following the procedure reported by Bertz and Dabbagh. ${ }^{6}$

Treatment of a THF solution of the trisylhydrazones 2 with 2.1 equivalents of $n$ butyllithium at $-78{ }^{\circ} \mathrm{C}$ gave deep orange coloured solutions. Upon warming to $0{ }^{\circ} \mathrm{C}$ for a few minutes, the evolution of nitrogen gas was evident leaving a yellow solution of vinyllithium species 3. This solution was then recooled to $-78{ }^{\circ} \mathrm{C}$. Preliminary investigations into the transmetallation-dimerisation were carried out with $\mathrm{MnCl}_{2}, \mathrm{Ti}(\mathrm{O} \mathrm{Pr})_{3} \mathrm{Cl}$ and $\mathrm{PhI}(\mathrm{OAc})_{2}$ giving no observable diene upon workup, although a combination of $\mathrm{Pd}(\mathrm{MeCN})_{2} \mathrm{Cl}_{2}$ and $\mathrm{CuCl}_{2}$ produced $4 \mathrm{a}$ in low yield $(43 \%)$.It is known that vinyllithium reagents undergo transmetallation to organocopper species and that these can undergo oxidative coupling to produce 1,3-dienes. ${ }^{7} \mathrm{~A}$ range ${ }^{8}$ of copper(I) salts were therefore employed to effect the dimerisation of the vinyllithium reagent derived from trisylhydrazone $2 \mathrm{a}$ (Table, entry i). The use of copper(I) iodide gave good yields for the formation of $4 \mathrm{a}$ (66-78\%) but was not general. The optimum procedure, and the one which appeared the most general, involved the 
use of one equivalent of $\left(\mathrm{CuI} . \mathrm{PBu}_{3}\right)_{4}{ }^{7 \mathrm{a}}$ in THF at $-78{ }^{\circ} \mathrm{C}$ followed by warming to room temperature and stirring at this temperature for 18 hours. The efficiency of $\left(\mathrm{CuI}^{\mathrm{PBB}} \mathrm{Pu}_{4}\right.$ compared to other $\mathrm{Cu}(\mathrm{I})$ salts may well be due to its high solubility in THF. The optimised procedure produced diene $4 \mathrm{a}$ in $68 \%$ yield; no other products were observed indicating regioselective deprotonation at the methyl group as was anticipated. ${ }^{5}$ Diene $4 \mathrm{a}$ has been used to prepare protein kinase $\mathrm{C}$ inhibitors: this synthesis from nonanone (68\% over 2 steps) compares favourably with the published route from nonanoic acid (6 steps, ca. 10\%). ${ }^{3}$ Addition of $1 \%$ triethylamine to column chromatography eluents was found to be necessary to avoid double bond isomerisation, but when pure the dienes could be stored under a nitrogen atmosphere in the freezer for a number of months.

Two other 2,3-disubstituted butadienes were also prepared using this methodology (Table, entries ii and iv). In the case of cyclohexyl methyl ketone trisylhydrazone $2 b$, selective deprotonation of the methyl group occurred giving diene $4 \mathrm{~b}$ in good yield. Cyclohexyl ethyl ketone trisylhydrazone $2 \mathrm{c}$ did not produce any diene $4 \mathrm{c}$, however, apparently failing to undergo the Shapiro reaction and demonstrating a limitation of this methodology (Table, entry iii). In the case of acetophenone trisylhydrazone $2 \mathrm{~d}$ vinyllithium formation appeared to proceed normally but the coupling was sluggish (Table entry iv). In this example the reaction was heated to reflux for 18 hours after the addition of the copper complex: this produced $4 \mathrm{~d}$ in $23 \%$ yield (no diene was obtained under the standard conditions). It seems likely that this low yield reflects the thermal stability of the intermediate organocopper species.

Next, we investigated the use of cyclic ketones ultimately producing 1,2,3,4tetrasubstituted butadienes (Table entries v and vi). Efficient deprotonation of the hydrazones 2e-i could only be achieved by using a THF-TMEDA (9:1) solvent mixture in the Shapiro reaction, ${ }^{5 \mathrm{~b}}$ but the standard transmetallation-dimerisation conditions afforded dienes $4 \mathrm{f}$ and $4 \mathrm{~g}$ in satisfactory yield. No dienes were isolated from the reaction of cyclopentanone trisylhydrazone 2e but the low stability of cyclopentenyllithium prepared in this way has been noted previously. ${ }^{9}$ In the case of cyclododecanone trisylhydrazone $2 \mathrm{~h}$, no diene was obtained but a 53\% yield of cyclododecene was isolated, presumably indicating that the dimerisation may be precluded for steric reasons. Finally, the substituted cyclohexanone trisylhydrazone $2 \mathrm{i}$, underwent efficient transformation to give diene $4 \mathrm{i}$.

In summary, an efficient two-step procedure for the preparation of substituted buta-1,3dienes from ketones has been developed and information on the scope and limitations of the methodology has been established. 
Table 1. Yields of hydrazones 2 and dienes 4

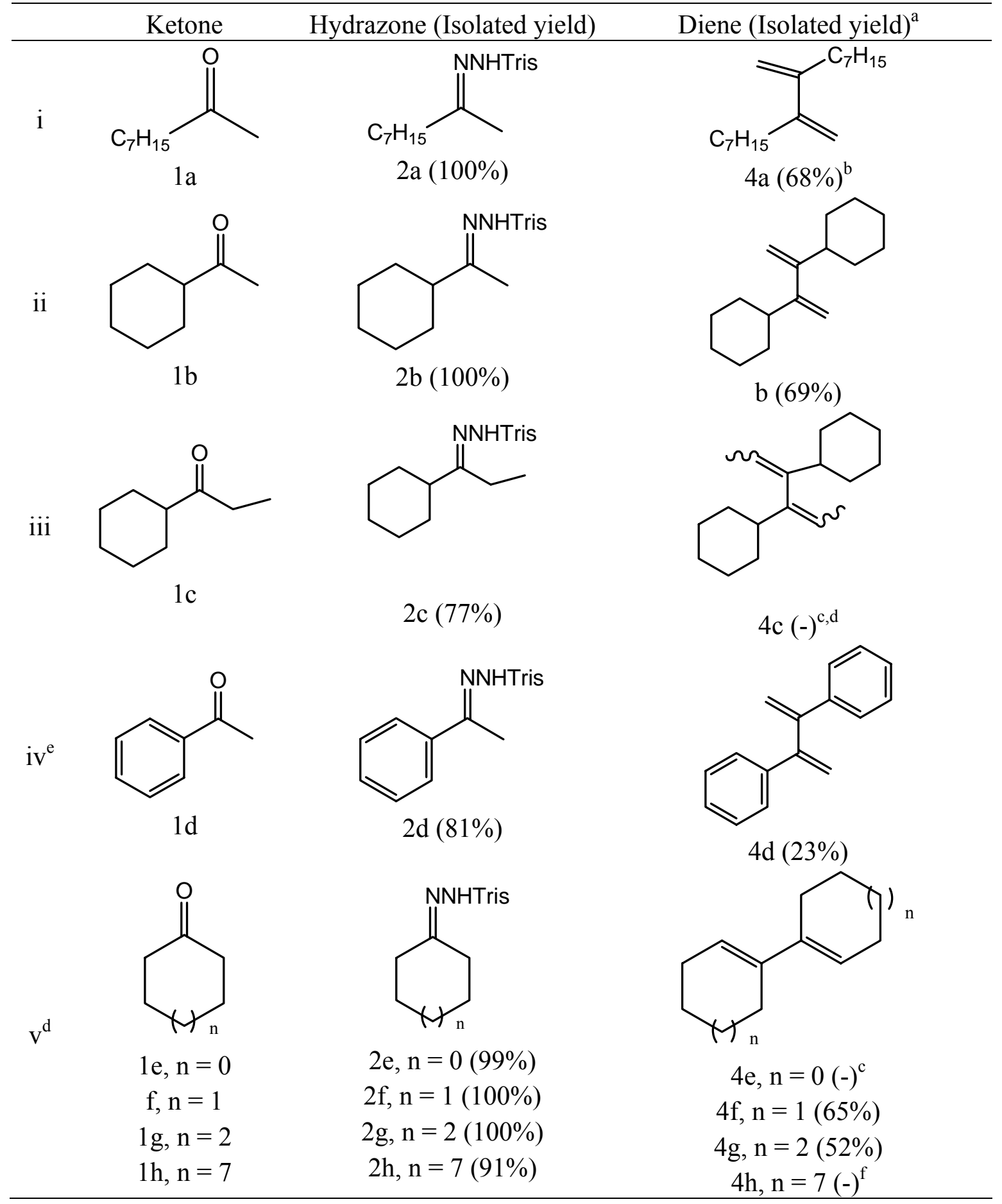


Table 1. Continued

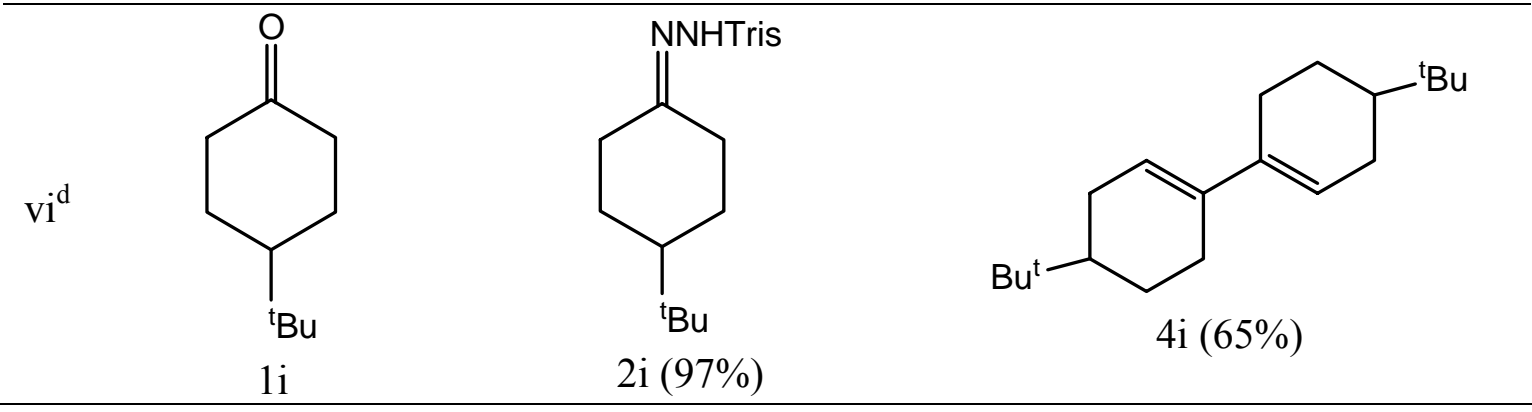

${ }^{\text {a }}$ Unless otherwise stated, $n$-BuLi in THF at $-78{ }^{\circ} \mathrm{C}$ was used for deprotonation. $\left(\mathrm{CuI} . \mathrm{PBu}_{3}\right)_{4}$ was added at $-78{ }^{\circ} \mathrm{C}$ followed by warming to room temperature and stirring at this temperature for 18 hours.

${ }^{\mathrm{b}}$ A $12 \%$ yield of a 1:1 mixture of $4 \mathrm{a}$ and 1-nonene was obtained with nonan-2-one tosylhydrazone, using $\mathrm{CuI}$ for the transmetallation. Using $2 \mathrm{a}$ and $\mathrm{CuI}, 4 \mathrm{a}$ was obtained in 66$78 \%$ yield.

${ }^{\mathrm{c}}$ None of the expected product was observed with only unidentified polar by-products being obtained.

${ }^{\mathrm{d}}$ THF-TMEDA (9:1) was used as solvent for the second step.

${ }^{\mathrm{e}}$ Coupling reaction heated to reflux for $18 \mathrm{~h}$ (no diene was obtained under standard conditions).

${ }^{\mathrm{f}}$ Cyclododecene (53\%) was obtained.

\section{Experimental Section}

Compounds $2 \mathrm{~b}-\mathrm{i}$ and $4 \mathrm{a}, \mathrm{b}, \mathrm{d}, \mathrm{f}, \mathrm{g}, \mathrm{i}$ are known andgave data consistent with those published.

\section{Representative Procedures}

\section{(a) Nonan-2-one trisylhydrazone (2a)}

To a stirred solution of trisylhydrazide $(1.49 \mathrm{~g}, 5 \mathrm{mmol})$ in THF $(35 \mathrm{~mL})$ was added nonan-2one $(0.85 \mathrm{~mL}, 5 \mathrm{mmol})$. After $3 \mathrm{~h}$, the solvent was removed in vacuo and the residue dried at $1 \mathrm{~mm} \mathrm{Hg}$ to give nonan-2-one trisylhydrazone $2 \mathrm{a}(2.13 \mathrm{~g}, 100 \%)$ as a colourless solid, $\mathrm{mp} 86$ - $88^{\circ} \mathrm{C}$ dec.; $R_{\mathrm{f}} 0.42$ (light petroleum - diethyl ether, 1:1); IR (Nujol ${ }^{\circledR}, \mathrm{cm}^{-1}$ ) $3242(\mathrm{NH}), 1599$, $1562,1379,1328,1167 ; \delta_{\mathrm{H}}\left(270 \mathrm{MHz}, \mathrm{CDCl}_{3}\right) 7.16(2 \mathrm{H}$, s, aromatic $), 4.22(2 \mathrm{H}$, sept., $J 7$ $\mathrm{Hz}, 2$ x $\left.\underline{\mathrm{HMe}}_{2}\right), 2.90\left(1 \mathrm{H}\right.$, sept., $\left.J 7 \mathrm{~Hz}, \mathrm{CHMe}_{2}\right), 2.17\left(2 \mathrm{H}, \mathrm{t}, J \mathrm{~Hz}, \mathrm{CH}_{2}\right), 1.90+1.77(3$ $\left.\mathrm{H}, 2 \times \mathrm{x}, \mathrm{CH}_{3}\right), 1.45-1.15\left(28 \mathrm{H}, \mathrm{m}, 5 \times \mathrm{CH}_{2}+6 \mathrm{x}\right.$ isopropyl $\left.\mathrm{CH}_{3}\right), 0.85\left(3 \mathrm{H}\right.$, br. t, $\left.\mathrm{CH}_{3}\right) ; \delta_{\mathrm{C}}$ 
$\left(67.9 \mathrm{MHz}, \mathrm{CDCl}_{3}\right)$ 157.0 (C), 153.0 (C), $151.3(2 \times \mathrm{C}), 131.4(\mathrm{C}), 123.6(2 \times \mathrm{CH}), 38.6$ $\left(\mathrm{CH}_{2}\right), 34.1(\mathrm{CH}), 31.6\left(\mathrm{CH}_{2}\right), 29.9(2 \times \mathrm{CH}), 28.8\left(\mathrm{CH}_{2}\right), 28.7\left(\mathrm{CH}_{2}\right), 25.8\left(\mathrm{CH}_{2}\right), 24.7(4 \mathrm{x}$ $\left.\mathrm{CH}_{3}\right), 23.5\left(2 \times \mathrm{CH}_{3}\right), 22.5\left(\mathrm{CH}_{2}\right), 15.2\left(\mathrm{CH}_{3}\right), 14.0\left(\mathrm{CH}_{3}\right) ; \mathrm{MS}(\mathrm{CI}) \mathrm{m} / \mathrm{z} 423\left(\mathrm{MH}^{+}, 100 \%\right)$, 281 (8), 251 (12), 157 (15) [HRMS (CI) 423.3050. $\mathrm{C}_{24} \mathrm{H}_{43} \mathrm{~N}_{2} \mathrm{O}_{2} \mathrm{~S}$ requires 423.3045 (1.1 ppm error)].

\section{(b) 2,3-Diheptylbuta-1,3-diene(4a)}

To a stirred solution of hydrazone $2 \mathrm{a}(0.422 \mathrm{~g}, 1 \mathrm{mmol})$ in dry THF $(5 \mathrm{~mL})$ at $-78{ }^{\circ} \mathrm{C}$ was added $n$-butyllithium $(2.5 \mathrm{M}$ solution in hexanes, $0.84 \mathrm{~mL}, 2.1 \mathrm{mmol})$ to give an orange solution. After stirring for $30 \mathrm{~min}$, the reaction was warmed to $0{ }^{\circ} \mathrm{C}$ for $5-10 \mathrm{~min}$ until nitrogen evolution had ceased. The yellow solution was then re-cooled to $-78{ }^{\circ} \mathrm{C}$ and added via cannula to a solution of $\left(\mathrm{CuI}^{\mathrm{PBBu}}\right)_{4}(1.571 \mathrm{~g}, 1 \mathrm{mmol})$ in dry THF $(5 \mathrm{~mL})$ at $-78{ }^{\circ} \mathrm{C}$. After $30 \mathrm{~min}$, the reaction was warmed to $\mathrm{rt}$ and stirred for $18 \mathrm{~h}$. The black reaction mixture was poured into satd. $\mathrm{NH}_{4} \mathrm{Cl}$ - conc. $\mathrm{NH}_{3}$ solution $(4: 1)(25 \mathrm{~mL})$ and diethyl ether $(25 \mathrm{~mL})$ and then filtered through Celite ${ }^{\circledR}$ into a separating funnel. After separation, the organic phase was washed with satd. $\mathrm{NaHCO}_{3}$ solution $(2 \times 25 \mathrm{~mL})$ and brine $(25 \mathrm{~mL})$, dried $\left(\mathrm{Na}_{2} \mathrm{SO}_{4}\right)$, filtered and the solvent removed under reduced pressure. The residue was purified by flash column chromatography (petroleum ether-Et $3 \mathrm{~N}, 99: 1$ ) to give 2,3-diheptylbuta-1,3-diene(4a) as a clear, colourless oil $(0.085 \mathrm{~g}, 68 \%), R_{\mathrm{f}} 0.56$ (light petroleum); with spectroscopic data consistent with those published. ${ }^{3,10}$

\section{Acknowledgements}

We are grateful to Dr. J. C. Briggs, P. G. Kerrod and B. R. P Stone for carrying out preliminary studies.

\section{References}

1. Dell, C. P. J. Chem. Soc., Perkin Trans. 1 1998, 3867 and references therein.

2. Taylor, R. J. K.; Hemming, K.; De Medeiros, E. F. J. Chem. Soc., Perkin Trans. 1 1995, 2385;Macdonald, G.; Alcaraz, L.; Wei, X.; Lewis, N. J.; Taylor, R. J. K. Tetrahedron 1998, 54, 9823 and references therein.

3. Briggs, J. C.; Haines, A. H.; Taylor, R. J. K.; Dawson, A. P.; Gibson, I.; Hook, J.; Lloyd, A.; Meiners, S. Carbohydrate Research 1992, 234, 23.

4. Alcaraz, L; Taylor, R. J. K. Synlett 1997, 791.

5. Shapiro, R.H. Org. React. 1976, 23, 405. (b) Chamberlain, A. R.; Bloom, S.H. Org. React. 1991, 39, 1.

6. Bertz, S. H.; Dabbagh, G. J. Org. Chem. 1983, 48, 116. 
7. Whitesides, G. M.; Casey, C. P.; Krieger, J. K. J. Am. Chem. Soc. 1971, 93, 1379; (b) Kauffman, T. Angew. Chem., Int. Ed. 1974, 13, 291.

8. Taylor, R. J. K. Organocopper Reagents, A Practical Approach; Oxford University Press: Oxford, 1994.

9. Jones, T. K.; Denmark, S. E. Helv. Chim. Acta 1983, 66, 2379.

10. Bender, D.; Müllen, K. Chem. Ber. 1988, 121, 1187. 